\begin{tabular}{|l|l|l||}
\hline \multicolumn{2}{|c|}{ PublisherInfo } \\
\hline \hline PublisherName & $:$ & BioMed Central \\
\hline \hline PublisherLocation & $:$ & London \\
\hline \hline PublisherImprintName & $:$ & BioMed Central \\
\hline \hline
\end{tabular}

\title{
The Ascultation Assistant
}

\begin{tabular}{|l|l|l||}
\hline \multicolumn{2}{|c||}{ ArticleInfo } \\
\hline \hline ArticleID & $:$ & 4294 \\
\hline \hline ArticleDOI & $:$ & $10.1186 /$ ccf-2000-webreport1863 \\
\hline \hline ArticleCitationID & $:$ & webreport1863 \\
\hline \hline ArticleSequenceNumber & $:$ & 35 \\
\hline \hline ArticleCategory & $:$ & Web report \\
\hline \hline ArticleFirstPage & $:$ & 1 \\
\hline \hline ArticleLastPage & $:$ & 3 \\
\hline \hline & $:$ & RegistrationDate : 2000-10-20 \\
ArticleHistory & $:$ & OnlineDate \\
\hline \hline ArticleCopyright & $:$ & Current Science Ltd2000-10-20 \\
\hline \hline ArticleGrants & $:$ & \\
\hline \hline ArticleContext & $:$ & 1305444 \\
\hline \hline
\end{tabular}




\section{Overview}

This site was created with the specific aim of teaching medical students the physical diagnosis of heart conditions. A number of heart sounds are presented, from a normal heartbeat to those sounds which occur in various disease states such as angina. Each sound is accompanied by a description of its pathophysiology. The author of the site is planning to add phonocardiographs in order to help students visualise the sounds that they are hearing.

\section{Content}

Although the site was designed with medical students in mind, it is certain to be a useful and interesting resource for anyone who wishes to learn more about heart sounds.

\section{Other comments}

23rd June 2000

\section{Evaluation}

None. However, in order to use the site, a computer equipped with a sound card and speakers is required. 


\section{References}

1. The Ascultation Assistant. [http://www.med.ucla.edu/wilkes/inex.htm]

This PDF file was created after publication. 